Portland State University

PDXScholar

\title{
Interactions between the Azoarcus Ribozyme and Manganese (II) Divalent Cations
}

Joshua Martwick

Portland State University

Follow this and additional works at: https://pdxscholar.library.pdx.edu/honorstheses

Part of the Chemistry Commons

Let us know how access to this document benefits you.

Recommended Citation

Martwick, Joshua, "Interactions between the Azoarcus Ribozyme and Manganese (II) Divalent Cations" (2020). University Honors Theses. Paper 823.

https://doi.org/10.15760/honors.842

This Thesis is brought to you for free and open access. It has been accepted for inclusion in University Honors Theses by an authorized administrator of PDXScholar. Please contact us if we can make this document more accessible: pdxscholar@pdx.edu. 


\title{
Interactions between the Azoarcus Ribozyme
} and Manganese (II) Divalent Cations

\author{
Joshua Martwick \\ Undergraduate Health Sciences Student \\ Department of Chemistry \\ Portland State University \\ Portland, Oregon \\ June 2019 \\ jm32@pdx.edu \\ Research Advisor: \\ Dr. Dirk Iwata-Reuyl \\ Professor of Chemistry \\ Department of Chemistry \\ Portland State University \\ Portland, Oregon \\ iwatareuyld@pdx.edu
}


Abstract........................................................................3

Introduction...............................................................4

Experimental Methods.................................................9

Results and Discussion..............................................12

References...........................................................18 


\begin{abstract}
$\underline{\text { Abstract }}$
The RNA world hypothesis suggests that RNA systems were the first form of life on the planet, beginning to appear approximately 4 billion years ago. Group I introns are self-splicing RNA elements in extant organisms and use $\mathrm{Mg}^{2+}$ as the principle divalent cation to promote catalysis. The group I intron ribozyme from Azoarcus is frequently used in origin of life studies, partially due to its autocatalytic abilities - the Azoarcus ribozyme is able to be broken into fragments and reassemble itself into its fully functional ribozyme. Previous work [1] identified metal binding sites on the Azoarcus ribozyme which use both potassium and magnesium ions, and suggest that other divalent ions, such as manganese (II), may be capable of substituting for $\mathrm{Mg}^{2+}$ in specific binding sites. The geological profile of the early earth suggests that manganese (II) was especially prevalent in nodules present on the ocean floor [2]. Compatibility with manganese (II) could have potentially offered a fitness advantage to early organisms occupying oceanic environments. We performed a series of experiments to demonstrate the catalytic ability of the Azoarcus ribozyme in various concentrations of $\mathrm{MnCl}_{2}$, using two different reaction mechanisms. We show that the catalytic activity of the Azoarcus ribozyme to be significantly improved when $\mathrm{Mg}^{2+}$ was replaced with manganese (II), but only when reacted with exogenous oligonucleotide substrate.
\end{abstract}




\section{Introduction}

Modern life is a capable and versatile natural force that has evolved over the last 4.3 billion years to survive in nearly every environment on Earth [1]. Organisms have tirelessly responded to extreme environmental pressures over countless millennia, and have developed with diversity ranging from independent, simple chemical systems to multicellular, socially cooperative organisms. The range of life seen today can theoretically be traced to a single point in history at which the first living system emerged from nonliving materials [3]. This theoretical spontaneous generation of biological molecules was first scientifically analyzed in 1924 when Alexander Oparin released his book titled The Origin of Life. Experiments throughout the 20th century, most notably the Miller and Urey experiments conducted in 1952, as well as the discovery of DNA the following year by Wilkins, Franklin, Watson, and Crick, have offered glimpses into the nature of the fundamental building blocks of life; however, an exact definition of life has remained elusive [4].

It is accepted that an event of abiogenesis would at the very least require molecules capable of organizing into a system capable of transmission, modification, and reproduction of genetic information [5]. In order to prevail for any lasting time frame, the organism would also need to be capable of making both genotypic and phenotypic adaptations in response to the pressures of natural selection over the course of multiple generations [6].

This turning point from inanimate substance to a biological organism has been an intriguing concept. The Miller Urey experiment famously showcased the plausible assembly of amino acids 
from a variety of smaller constituents. Amino acids are required for modern and ancient organisms, but it is unlikely that pioneering, simple living systems could make use of such materials due to the complex machinery required for their formation [7]. This began the hunt for a holy grail of biological materials - a molecule complex enough to be capable of maintaining, modifying, and transmitting genetic information between generations, but simple enough to spontaneously generate in an early earth setting and lay the groundwork for further complexity.

Various theories and ideas had been proposed until 1989 [8], when Sidney Altman and Thomas and Thomas R. Cech made an astounding discovery that bolstered the plausibility of the RNA world hypothesis - the catalytic properties of RNA. Both DNA and RNA are capable of independent reproduction and catalytic ability; however, ribose can form under prebiotic conditions, while deoxyribose can not. [9]. Further investigation revealed possible spontaneous generation of short oligonucleotide RNAs and demonstrated the possibility of extensive continuous polymerization [10]. Continuous elongation of RNA fragments may have provided sufficient lengths capable of assembling with a tertiary structure that further aided in catalytic and reproductive fitness [11].

The Azoarcus ribozyme is a relatively well studied, ancient RNA [12]. The Azoarcus ribozyme is a Group I intron approximately 200 nucleotides in length and primarily operates through two reaction mechanisms. The first is defined as the "pick-up-the-tail reaction" (PUTT reaction) in which the full length ribozyme cleaves an exogenous substrate [13]. In vivo, this reaction serves as a functional self splicing mechanism in the Azoarcus bacterial genome. 
This reaction begins with the binding of the exogenous substrate to the internal guide sequence (IGS). The IGS is a highly conserved sequence responsible for holding the exogenous substrate in a favorable position relative to the intron. The IGS positions the 5' splice site of the ribozyme into the active site, and aligns itself with the 3 ' splice site. The exogenous substrate binds to the IGS, and the 3' hydroxyl of the ribozyme enters the binding pocket near the 5' splice site. The 3' hydroxyl of the terminal guanosine acts as a nucleophile to attack the 5' phosphate of the splice site specified on the substrate. During the transition state of the reaction, the geometry of the phosphorus is pentacovalent. The guanosine is ligated to the ribozyme at its 3 ' hydroxyl along with the tail end of the substrate, and the remaining 5' substrate remains bound to the IGS in the active site. Geometric rearrangement of the intron facilitates the release of the substrate. This concludes the PUTT reaction. The original 200 nucleotide trans complex is elongated, and the 
exogenous substrate is cleaved into two fragments as shown in Figure 1.
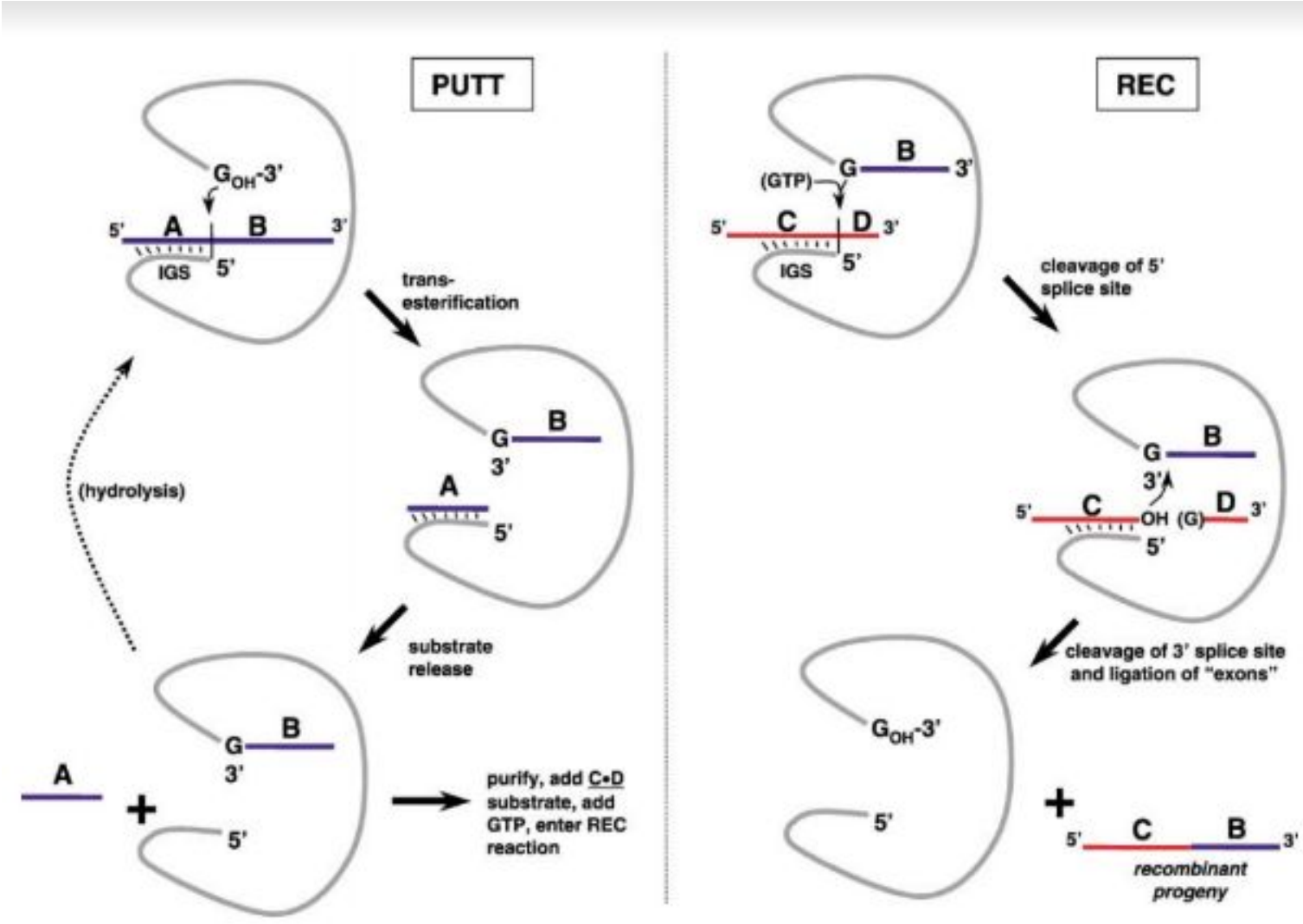

Figure 1: An illustration of pick up the tail and recombination reaction mechanisms of the Azoarcus ribozyme.

Source: Craig A. Riley, Niles Lehman, Generalized RNA-Directed Recombination of RNA, Chemistry \& Biology, Volume 10, Issue 12, 2003, Pages 1233-1243, ISSN 1074-5521, http://dx.doi.org/10.1016/j.chembiol.2003.11.015.

(http://www.sciencedirect.com/science/article/pii/S1074552103002680)

The ribozyme is also capable of recombination (REC). [13]. This process begins with the pick-up-the-tail reaction, however, if the 3' end of the first substrate diffuses out of the catalytic pocket, or can be competitively displaced by a second substrate, then the ribozyme is able to promote the nucleophilic attack of guanosine on the second substrate, thereby catalyzing recombination of a new product. 
The Azoarcus ribozyme possesses the unique quality of being able to be broken into five fragments that are capable of reassembly into the fully functional, catalytically active complex for further reproduction [14] via the REC mechanism. Self assembly is complex and occurs through a variety of competitive and cooperative networks according to environmental pressures on the reproductive system [15].

Research has been performed with Azoarcus in the context of self assembly and investigation of its catalytic capabilities, but has primarily been investigated in the presence of the cofactor $\mathrm{Mg}^{2+}$ [16]. Examination of the geological timescale of the early Earth reveals that other metals such as $\mathrm{Mn}^{2+}$ and $\mathrm{Fe}^{2+}$ could have been more or equally abundant as $\mathrm{Mg}^{2+}[17]$, especially since the Great Oxidation event did not occur until hundreds of millions of years after the hypothesized origin of life $[17,18]$. Previous attempts to perform catalytic and self assembly reactions with Azoarcus in the absence of $\mathrm{Mg}^{2+}$ have failed or shown negligent yields [18]. Here we show that $\mathrm{Mn}^{2+}$ can enhance catalytic capabilities of the Azoarcus ribozyme in a trans configuration, PUTT reaction, and we speculate on how the tertiary structure of Azoarcus affects cofactor compatibility according to previous research [19]. 


\section{Materials \& Methods}

RNA Preparation: Both WXYZ (200-nt) and WXY (148-nt) RNA samples were initially prepared via VATR (Vent Assisted Template Reconstruction). Thermococcus litoralis (Vent) is a DNA polymerase that facilitates the assembly of these fragments. These templates were amplified via the polymerase chain reaction. The assembled double stranded DNA was purified via an ethanol precipitation and rehydrated in UltraPure Ambion $\mathrm{H}_{2} \mathrm{O}$. Standard in vitro transcription was performed using T7 RNA polymerase in transcription buffer and equal concentrations of all four ribonucleotide triphosphate molecules (ATP, GTP, UTP, CTP) plus rehydrated PCR products. This mixture was incubated at $48^{\circ} \mathrm{C}$ for approximately $6-8$ hours. The transcribed RNA was then separated via phenol/chloroform organic extraction. An ethanol precipitation was performed and the product was purified by means of polyacrylamide gel electrophoresis. The RNA product was resuspended in Ethylenediaminetetraacetic acid (EDTA) at a concentration of $0.1 \mathrm{mM}$ and diluted before being analyzed on a NanoDrop photospectrometer.

Buffer Preparation: Reaction buffer stocks were prepared by addition of $150 \mu \mathrm{L}$ of $1 \mathrm{M} \mathrm{EPPS} \mathrm{pH}$ 7.5 to $500 \mu \mathrm{L}$ respective metal buffer $\left(100 \mathrm{mM} \mathrm{MgCl}_{2}, 10 \mathrm{mM} \mathrm{MgCl}_{2}\right.$, or $\left.10 \mathrm{mM} \mathrm{MnCl}_{2}\right)$ and $350 \mu \mathrm{L}$ of UltraPure Ambion $\mathrm{H}_{2} \mathrm{O}$. Quench was added to the reaction to interrupt reaction activity at a volume of $7 \mu \mathrm{L}$ ( 2 parts $0.5 \mathrm{M}$ EDTA and 3 parts $2 \mathrm{X}$ polyacrylamide gel loading dye with $8 \mathrm{M}$ urea). 
Experimental Preparation: Three sets of five $600 \mu \mathrm{L}$ tubes were labeled in series. The first series acted as a control (50 $\mathrm{mM} \mathrm{Mg}^{2+}$ trans-splicing buffer) compared against two separate experimental series ( $5 \mathrm{mM} \mathrm{Mg}^{2+}$ buffer and $5 \mathrm{mM} \mathrm{Mn}^{2+}$ buffer). Each of the four tubes in each series were labeled at timepoints as following: Reaction tube, $0^{\prime}, 30^{\prime}, 60^{\prime}, 120^{\prime}$. For the pick-up-the-tail reaction, WXYZ RNA and SNL-1a substrate (table 1) were diluted to a ratio of 1 $\mu \mathrm{M}: 2.5 \mu \mathrm{M}$ within the reaction tubes. For the WXY+Z Self Assembly, WXY RNA and Z RNA were diluted to a ratio of $1 \mu \mathrm{M}: 1 \mu \mathrm{M}$ within the reaction tubes. At $0^{\prime}, 30^{\prime}, 60^{\prime}$, and $120^{\prime}, 1{ }^{\prime}$ of the reaction tube volume was removed and combined with an equal volume of Quench in the respective time point tubes to terminate the reactions at the appropriate time point. Reaction tubes were incubated at $80^{\circ} \mathrm{C}$ for 1 minute.

Equal volumes of trans-splicing buffer were added to reaction tubes and time points were taken immediately thereafter. Reaction tubes were incubated at $48^{\circ}$ for the duration of the reaction.

Quenched samples were loaded on an $8 \%$ polyacrylamide analytic gel (8M urea) and run at $800 \mathrm{~V}$ for 2 hours. The gel was exposed to SyBr Green Visualization dye and examined using fluorescence imaging on a Typhoon Trio+. Reaction bands were analyzed using ImageQuant and calculated using the following formula:

$$
\% \text { reacted }=[\text { reacted } /(\text { reacted }+ \text { unreacted })] * 100
$$

Typhoon quantification techniques identify the opacity of procedurally generated cells centered around reactant and product bands. This introduces the possibility for varying amounts of error in quantitative results, as gel imaging opacity can vary depending on the quality of the staining 
procedure and presence of residual, unpolymerized polyacrylamide in wells prior to the running of the gel.

Table 1: Exogenous substrate used in PUTT reaction.

\begin{tabular}{|l|l|l|}
\hline $\begin{array}{l}\text { RNA } \\
\text { Oligo }\end{array}$ & Sequence & Length \\
\hline SNL-1a & $\begin{array}{l}\text { GGCAU•AAAUAAAUA } \\
\text { AAUAAAUA }\end{array}$ & 22-mer \\
\hline
\end{tabular}




\section{$\underline{\text { Results \& Discussion }}$}

A series of experiments were conducted to directly assess the ability of the Azoarcus ribozyme to function catalytically in the presence of manganese divalent ions. The first experiment analyzed the PUTT with the full length ribozyme and exogenous substrate at concentrations of $10 \mathrm{mM}$ $\mathrm{MnCl}_{2}, 10 \mathrm{mM} \mathrm{MgCl}$, and $100 \mathrm{mM} \mathrm{MgCl}_{2}$. Trans-splicing buffers were prepared and the experiments were performed according to the PUTT procedure as detailed in the methods section. Results are noted (figure 2) below.

Quantification of bands shows the total percentage of Azoarcus that reacted with substrate (table 2). Due to error in quantification software and presence of background opacity on gel, some reaction is noted at 0 ' time points. This is especially notable in the $100 \mathrm{mM} \mathrm{Mg}$ segment, in which a significant amount of product was noted at the 0 ' time point, possibly due to unpolymerized polyacrylamide.

Visual qualitative assessment of gel electrophoresis results can be used in addition to quantitative analysis to analyze the viability of the ribozyme in the presence of manganese (II) ions. It is noted upon examination of each band that both magnesium and manganese based solutions yielded a product band to varying degrees of opacity, and that the Azoarcus ribozyme is indeed active with manganese (II) ions. 


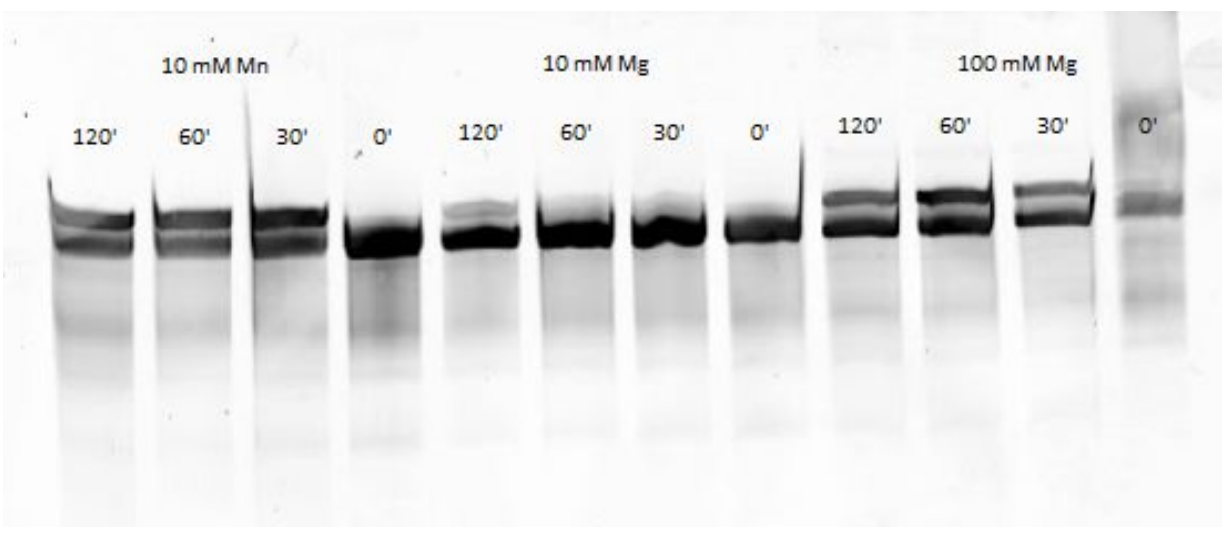

Figure 2: The results of a pick up the tail reaction in varying concentrations of 5x t-x Manganese buffer and Magnesium buffer. Time points were taken at $0^{\prime}, 30^{\prime}, 60^{\prime}$, and 120'. SNL-1a was present in the reaction at a concentration of $2.5 \mu \mathrm{M}$, and WXYZ was present at a concentration of $1 \mu \mathrm{M}$.

Table 2: Quantitative results of the PUTT reaction with varying concentrations of manganese and magnesium.

\begin{tabular}{|c|c|c|c|}
\hline \multirow{2}{*}{ Time } & \multicolumn{3}{|c|}{$\%$ Reaction } \\
\cline { 2 - 4 } & $\begin{array}{c}10 \mathrm{mM} \\
\mathrm{Mn}\end{array}$ & $\begin{array}{c}10 \mathrm{mM} \\
\mathrm{Mg}\end{array}$ & $\begin{array}{c}100 \mathrm{mM} \\
\mathrm{Mg}\end{array}$ \\
\hline 0 & 5.20 & 12.81 & 41.04 \\
\hline 120 & 43.18 & 15.93 & 31.86 \\
\hline
\end{tabular}

With evidence that manganese (II) ions were able to support the catalytic activity of the Azoarcus ribozyme, efforts were taken to understand the operational boundaries of manganese based PUTT reactions. Further investigation of concentration correlated with an improved yield with an optimal concentration identified at $45 \mathrm{mM} \mathrm{MnCl}_{2} 5 \mathrm{x}$-tx buffer with a percent reaction of $87 \%$, as shown in Table 2. As noted previously, the extent of the percent reaction requires further investigation. 


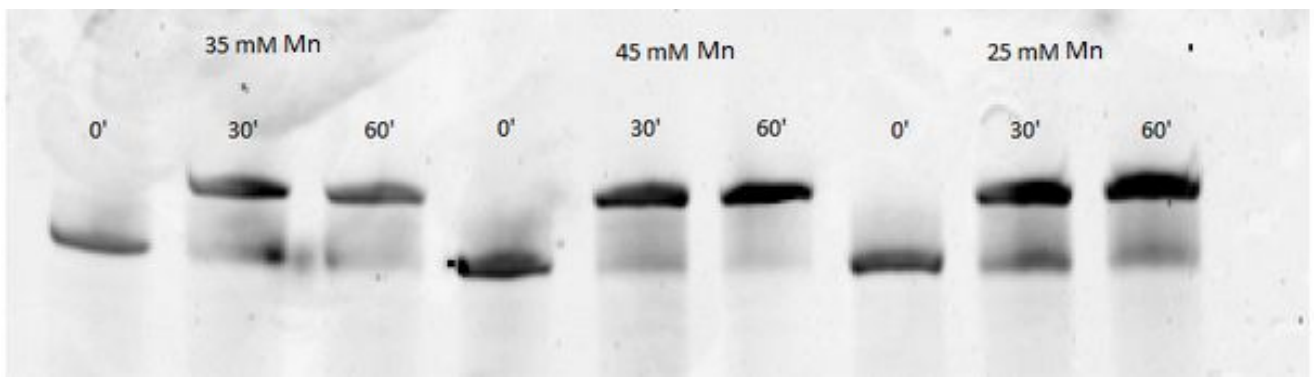

Figure 3: The results of a pick up the tail reaction in varying concentrations of $5 \mathrm{x} t-\mathrm{x}$ Manganese buffer. Time points were taken at $0^{\prime}, 30^{\prime}$, and $60^{\prime}$. SNL-1a was present in the reaction at a concentration of $2.5 \mu \mathrm{M}$, and WXYZ was present at a concentration of $1 \mu \mathrm{M}$.

Table 3: Quantitative results of the PUTT reaction with varying concentrations of manganese and magnesium.

\begin{tabular}{|c|c|c|c|}
\hline \multirow[b]{2}{*}{ Time } & \multicolumn{3}{|c|}{$\%$ Reaction } \\
\hline & $\begin{array}{c}25 \mathrm{mM} \\
\mathrm{Mn}\end{array}$ & $\begin{array}{c}35 \mathrm{mM} \\
\mathrm{Mn}\end{array}$ & $\begin{array}{c}45 \\
\mathrm{mM} \\
\mathrm{Mn}\end{array}$ \\
\hline $0^{\prime}$ & 6.81 & 3.57 & 10.15 \\
\hline $30^{\prime}$ & 64.1 & 66.03 & 69.63 \\
\hline $60^{\prime}$ & 67.01 & 70.22 & 85.65 \\
\hline
\end{tabular}

Covalent self assembly reactions were tested at the same range of concentrations as the PUTT with no detectable reaction at any concentrations as shown in figure 4. 

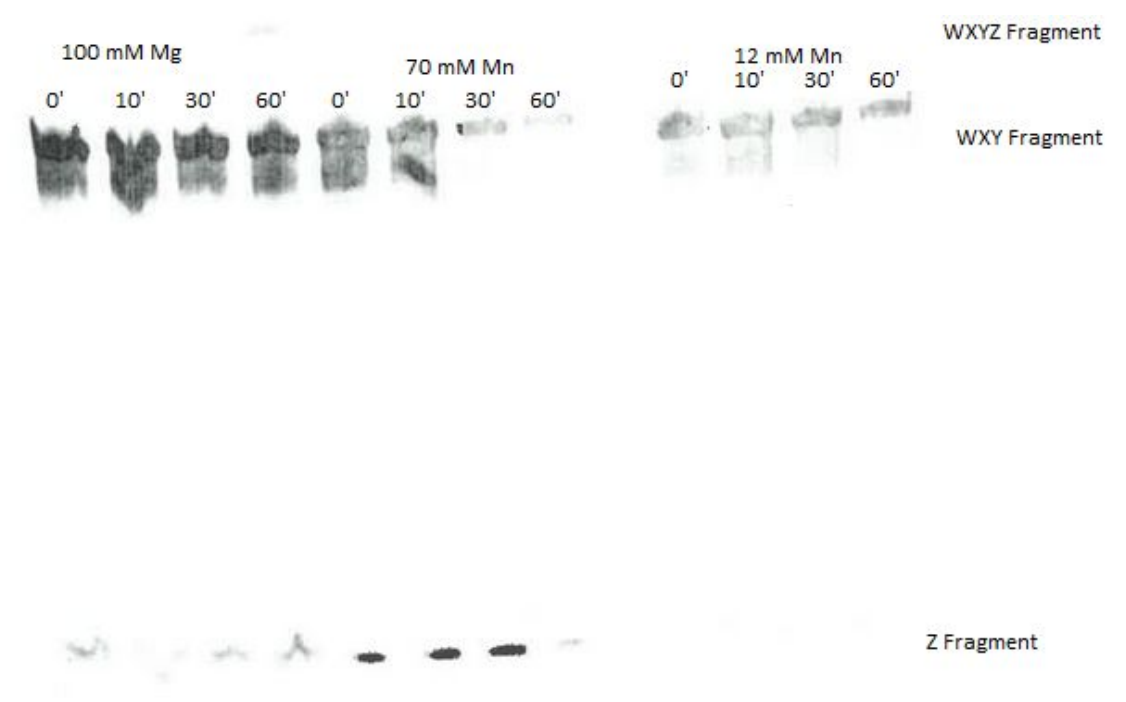

Figure 4: The results of a self assembly reaction in varying concentrations of $5 \mathrm{x} t$-x Manganese buffer. Time points were taken at $0^{\prime}, 10^{\prime}, 30^{\prime}$, and $60^{\prime}$. Z was present in the reaction at a concentration of $1 \mu \mathrm{M}$, and WXY was present at a concentration of $1 \mu \mathrm{M}$.

The discrepancy between the results of covalent self assembly and the PUTT reactions is not

fully understood, and requires further investigation to better identify the underlying mechanisms at play. However, previous work [18] as shown in figures 5 and 6 identified the crystal structure of the Azoarcus group 1 intron, and further identified key binding sites essential in different reaction mechanisms. The P4-P6 binding sites were identified as a scaffold for the entirety of the intron. M1-M2, M5, and M12 were identified as the core metals, and make contact directly with the scaffold, while M8-M11 and M14-M16 also bind to P4. Other metal groups in the surrounding regions were found to be essential for structural stability [18, 19]. 


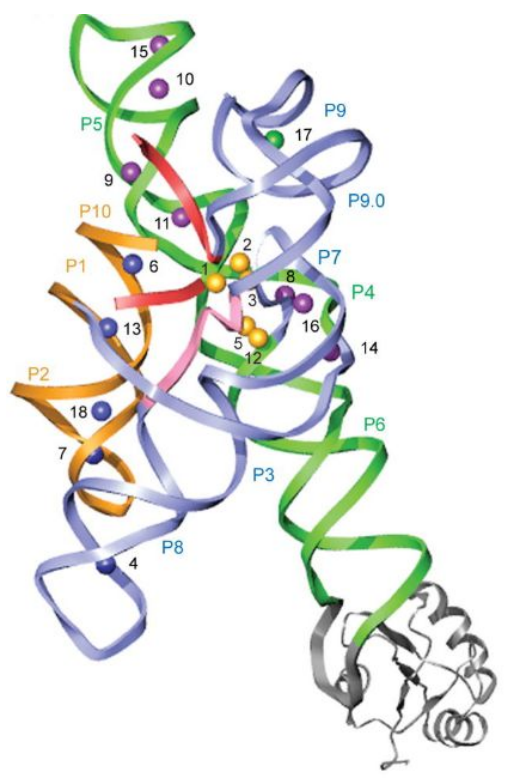

Figure 5: Ribbon diagram of the Azoarcus group I intron pre-2S deoxy- $\Omega$ G (PDB 1U6B) crystal structure with metals indicated as spheres. Metal numbering indicated are used throughout the text. Metal sphere color indicates binding region: core metals are orange; P10-P2, P8 metals are blue; P4-P6 metals are purple; the P9.0-9 metal is green.

Source: Stahley, M. R., Adams, P. L., Wang, J., \& Strobel, S. A. (2007). Structural metals in the group I intron: a ribozyme with a multiple metal ion core. Journal of Molecular Biology, 372(1), 89-102.

http://doi.org/10.1016/j.jmb.2007.06.026
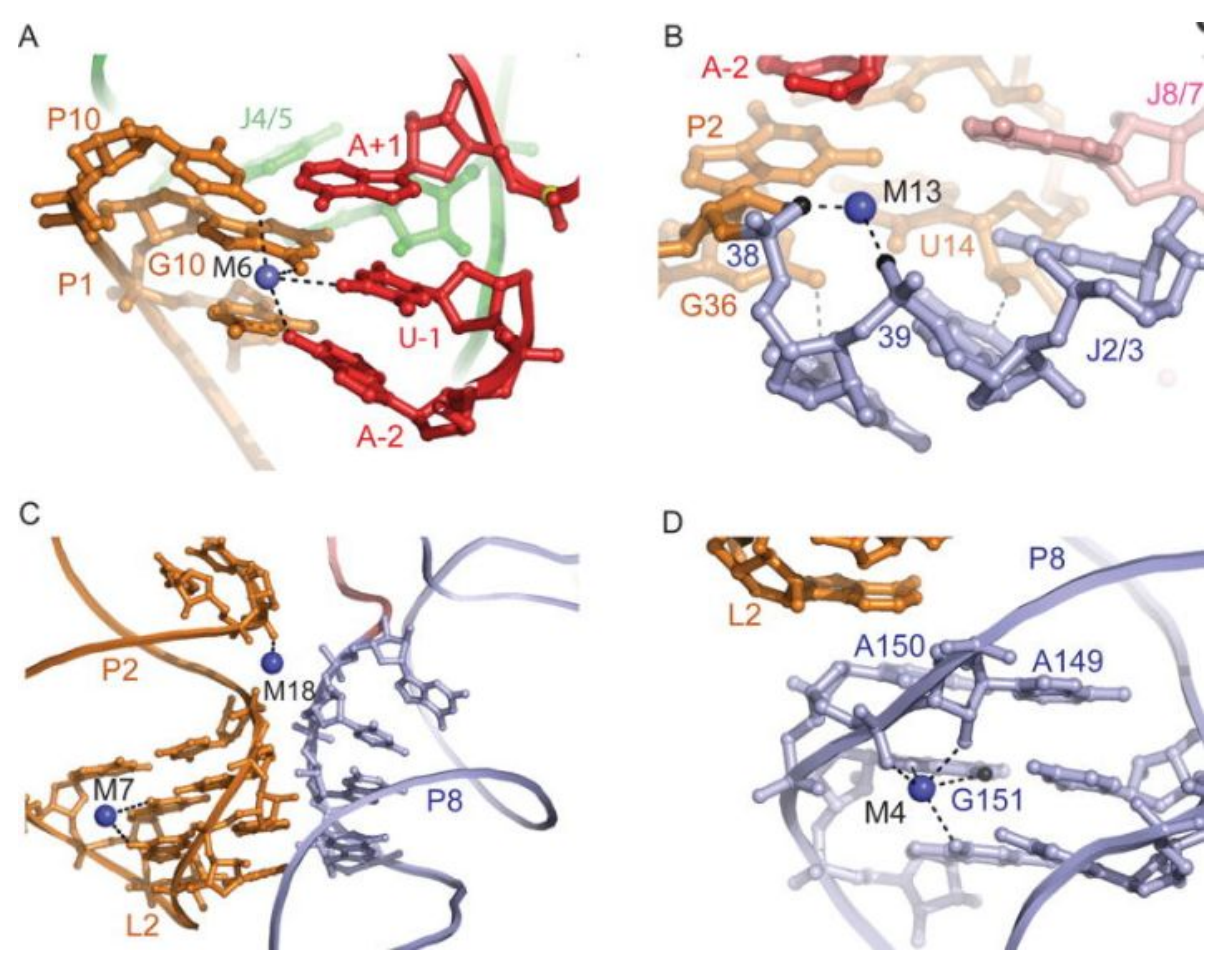

Figure 6: Visual mapping of M6, M13, M7, M18, and M4 (K+ ions).

Source: Source: Stahley, M. R., Adams, P. L., Wang, J., \& Strobel, S. A. (2007). Structural metals in the group I 
intron: a ribozyme with a multiple metal ion core. Journal of Molecular Biology, 372(1), 89-102.

http://doi.org/10.1016/j.jmb.2007.06.026

Previous metal rescue experiments with Azoarcus have been attempted in the past using $\mathrm{Ca}^{2+}$ ions with no noted activity [17]. Reaction yield was noted after RT-PCR, which utilized in vitro selection to facilitate mutant strands of Azoarcus compatible with the large divalent ions. Utilizing similar methods may be fruitful for investigating compatibility of $\mathrm{Mn}^{2+}$ ions with mutant strands of Azoarcus and further honing in on the mutations required to alter the specificity of the target metal binding sites. 


\section{References:}

1. Dodd, M. S., Papineau, D., Grenne, T., Slack, J. F., Rittner, M., Pirajno, F., O'Neil, J., Little, C. T.S., "Evidence for early life in Earth's oldest hydrothermal vent precipitates" (2017). Nature 543 (7643): 60-64.

2. Sleep, Norman H. "The Hadean-Archaean environment" (2010). Cold Spring Harbor perspectives in biology vol. 2,6; a002527.

3. Yarus, M., "Life from an RNA World: The Ancestor Within" (2010). Cambridge, MA: Harvard University Press. ISBN 978-0-674-05075-4. LCCN 2009044011.

4. Emmeche, C., Defining Life, Explaining Emergence. Center for the Philosophy of Nature and Science Studies (1997). Print.

5. Hayden, E.J., and Lehman, N., "Self assembly of a group I intron from inactive oligonucleotide fragments" (2006). Chemistry and Biology 13(8): 909-918.

6. Joyce, G.F., and Orgel, L.E., "Prospects for understanding the origin of the RNA world" (1999). RNA World Second Edition, pp. 49-77.

7. Noller, H. F., "Evolution of protein synthesis from an RNA world" (2012). Cold Spring Harbor Perspectives in Biology 4 (4): a003681. doi:10.1101/cshperspect.a003681. PMC 3312679. PMID 20610545.

8. Bernal, J.D., [Reprinted work by A.I. Oparin originally published 1924; Moscow: The Moscow Worker] The Origin of Life The Weidenfeld and Nicolson Natural History. (1967) Translation of Oparin by Ann Synge. London: Weidenfeld \& Nicolson. LCCN 67098482. Print.

9. Copley, S. D., Smith, E., Morowitz, H. J., "The origin of the RNA world: co-evolution of genes and metabolism” (2007). Bioorganic Chemistry. 35 (6): 430-43. doi:10.1016/j.bioorg.2007.08.001. PMID 17897696.

10. Lutay, A. V., Marina, A. Z., Vlassov, V. V., "Nonenzymatic Recombination of RNA: Possible Mechanism for the Formation of Novel Sequences" (2007). Laboratory of Nucleic Acids Biochemistry, Institute of Chemical Biology and Fundamental Medicine. SB RAS, Lavrentiev Ave, 8, Novosibirsk, 630090, Russian Federation, vol. 4.

11. Vaidya, N., Manapat, M., Chen, I.A., Xulvi-Brunet, R., Hayden, E.J., Lehman, N., "Spontaneous network formation among cooperative RNA replicators" (2012). Nature. 491(7422).

12. Chen, X., Miché, L., Sachs, S., Wang, Q., Buschart, A., Yang, H., ... Reinhold-Hurek, B. "Rice responds to endophytic colonization which is independent of the common symbiotic signaling pathway" (2015). New Phytologist. Vol 208-02;13458

13. Riley, C. A., Lehman, N., "Generalized RNA-Directed Recombination of RNA" (2003). Chemistry \& Biology, Volume 10, Issue 12, Pages 1233-1243, ISSN 1074-5521

14. Jayathilaka, T.S., Lehman, N., "Spontaneous covalent self-assembly of the Azoarcus ribozyme from five fragments" (2018). Chembiochem. 19(3): 217-220. 
15. Ramprasad, S., "Topological Structures Influencing Kinetic Control in Small, Catalytically Closed, RNA Recombinase Systems Emerging from the Spontaneous Self-Organization of Heterogeneous Fragments of the Azoarcus Ribozyme" (2018). University Honors Theses. Paper 607.

16. Prashanth, R., et al. "Architecture and Folding Mechanism of the Azoarcus Group I Pre-TRNA.” (2004). Journal of Molecular Biology. 329(2):229-238

17. Burton, AS., Lehman, N., "Calcium(II)-dependent catalytic activity of the Azoarcus ribozyme: testing the limits of resolution for in vitro selection" (2006). Biochimie, Jul;88(7) PMID: 16494986 DOI: 10.1016/j.biochi.2006.01.010

18. Stahley, M. R., Adams, P. L., Wang, J., \& Strobel, S. A., "Structural metals in the group I intron: a ribozyme with a multiple metal ion core" (2007). Journal of Molecular Biology, 372(1), 89-102. http://doi.org/10.1016/j.jmb.2007.06.026

19. Gleitsman, K. R., \& Herschlag, D. H. "A kinetic and thermodynamic framework for the Azoarcus group I ribozyme reaction" (2014). RNA. 1732-46. doi:

10.1261/rna.044362.114. 